\title{
Experimental Evaluation of Supercapacitor-Fuel Cell Hybrid Power Source for HY-IEL Scooter
}

\author{
Piotr Bujlo, ${ }^{1,2}$ Grzegorz Pasciak, ${ }^{1}$ Jacek Chmielowiec, ${ }^{1}$ and Andrzej Sikora ${ }^{1}$ \\ ${ }^{1}$ Electrotechnical Institute Wroclaw Division of Technology and Materials Science, M. Sklodowskiej-Curie 55/61, \\ 50-369 Wroclaw, Poland \\ ${ }^{2}$ Hydrogen South Africa (HySA) Systems and Validation Centre, University of the Western Cape, \\ Robert Sobukwe Road, Bellville, Cape Town 7535, South Africa
}

Correspondence should be addressed to Piotr Bujlo; pbujlo@gmail.com

Received 30 January 2013; Revised 23 April 2013; Accepted 23 April 2013

Academic Editor: Mattheos Santamouris

Copyright (C) 2013 Piotr Bujlo et al. This is an open access article distributed under the Creative Commons Attribution License, which permits unrestricted use, distribution, and reproduction in any medium, provided the original work is properly cited.

\begin{abstract}
This paper presents the results of development of a hybrid fuel cell supercapacitor power system for vehicular applications that was developed and investigated at the Energy Sources Research Section of the Wroclaw Division of Electrotechnical Institute (IEL/OW). The hybrid power source consists of a polymer exchange membrane fuel cell (PEMFC) stack and an energy-type supercapacitor that supports the system in time of peak power demands. The developed system was installed in the HY-IEL electric scooter. The vehicle was equipped with auxiliary components (e.g., air compressor, hydrogen tank, and electromagnetic valves) needed for proper operation of the fuel cell stack, as well as electronic control circuits and a data storage unit that enabled on-line recording of system and vehicle operation parameters. Attention is focused on the system energy flow monitoring. The experimental part includes field test results of a vehicle powered with the fuel cell-supercapacitor system. Values of currents and voltages recorded for the system, as well as the vehicle's velocity and hydrogen consumption rate, are presented versus time of the experiment. Operation of the hybrid power system is discussed and analysed based on the results of measurements obtained.
\end{abstract}

\section{Introduction}

Hydrogen becomes a more reliable future energy carrier and its usage as fuel for fuel cells becomes a more and more probable future method for electric energy production. This statement can be supported by a large number of scientific papers that present the latest developments on fuel cell technology [1-3], innovative fuel cell stationary [4,5], and mobile and automotive applications [6-8], as well as considerations on hydrogen economy prospects [9-11].

Polymer exchange membrane fuel cell (PEMFC) is the most promising fuel cell type for future commercialization and application. Although PEMFC has suitable parameters for the previously mentioned applications, among others low operating temperature and high current density, it cannot serve as the only energy source in the power system. Hybridization of power sources is needed to provide immediate power supply for auxiliary devices during the fuel cell start-up and to supply power during peak demands. The latter is important especially in the case of automotive applications where load changes are sudden and the power train requires an immediate power supply for a comfortable drive. There are literature reports concerning battery/fuel cell hybrid systems $[12,13]$. Because the battery presents some drawbacks, such as low life cycle, long recharging time and low power density, it is more reasonable to use supercapacitors that overcome the previously mentioned problems with batteries.

In the literature there are many papers describing the projects of fuel cell powered lightweight vehicles, such as and Pios-hydrogen powered tricycle [17], HYSYRIDERfuel cell based electric scooter [18], and MHV and HFCHVhydrogen fuel cell vehicle $[15,16]$, a few concepts of fuel cell powered electric bicycles [14] and hydrogen fuel cell hybrid vehicles $[20,21]$ and scooters $[19,22]$. Typically, batteries are applied as an energy buffer because a standalone fuel cell system integrated into an electric drive is not always sufficient to provide the load demands of a vehicle [23]. In order to provide the peak power during such transients as start-up, 


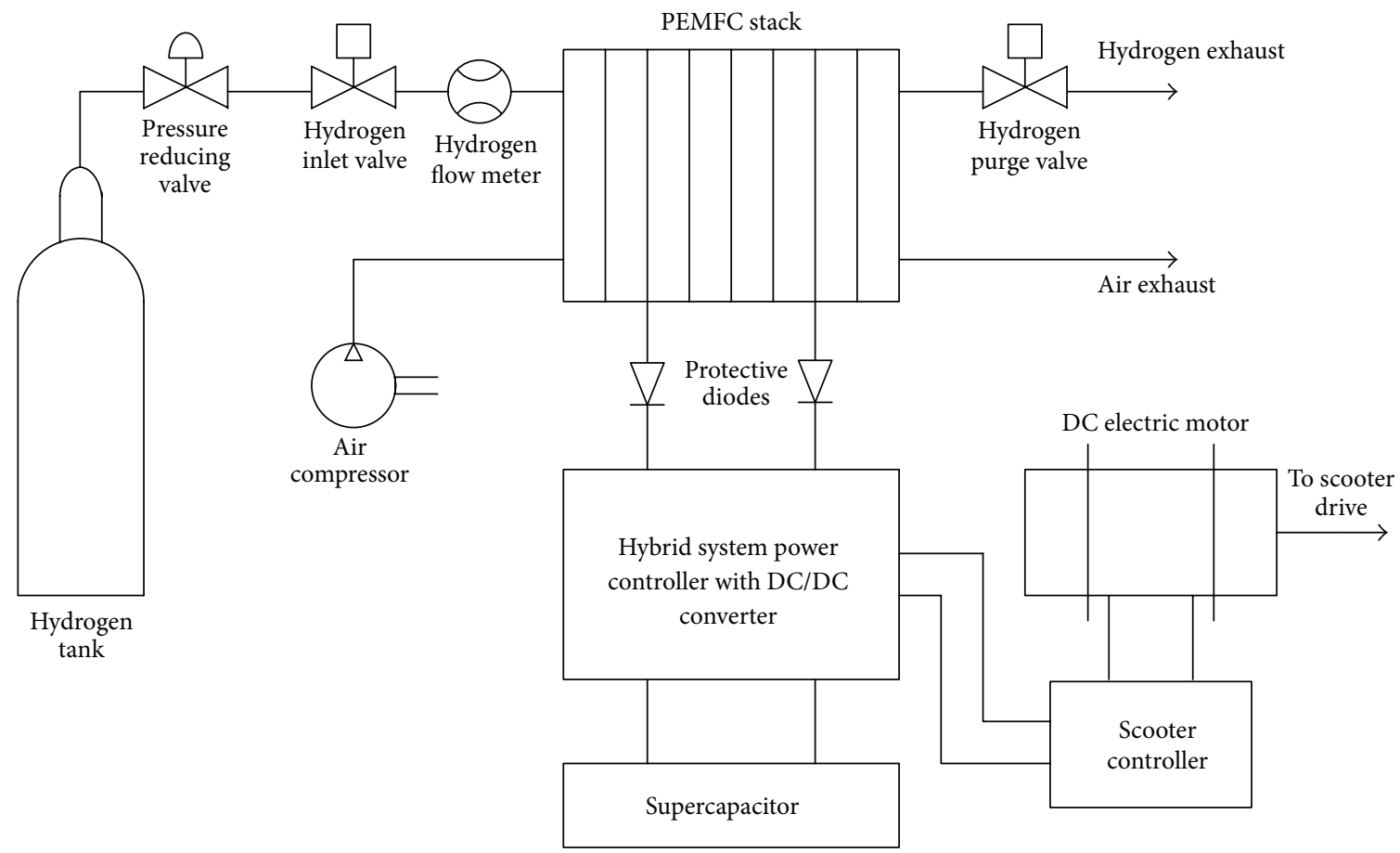

FIGURE 1: Component layout diagram of the Hy-IEL scooter showing hybrid system components and electrical drive train.

acceleration or sudden changes in load and also to take advantage of the regenerative power of an electric vehicle during braking, it is much more suitable to use a supercapacitor in addition to the fuel cell stack $[20,21]$. The primary purpose of using a supercapacitor instead of batteries as the energy buffer is that a supercapacitor provides better power densities than conventional batteries and better energy densities than conventional capacitors. The results of research and measurements have proved that a supercapacitor can be interchangeably used instead of batteries for vehicular applications.

This paper deals with an experimental evaluation of the supercapacitor-fuel cell hybrid power source implemented on an Hy-IEL electric vehicle. Operating parameters of the hybrid power source and the vehicle are measured and stored during field tests. Operation of the hybrid power system is discussed and analysed based on the results of measurements obtained.

\section{Hybrid Power Source Integration in a Vehicle}

System technical specification and the components were selected taking into account available fuel cell stack and its parameters as well as vehicle electric motor requirements. The construction of the developed hybrid system consists of the ANUVU fuel cell stack with $500 \mathrm{~W}$ of nominal power, operating with the efficiency of up to $40 \%$ at $70 \mathrm{~A}$ and two MAXWELL supercapacitors with a nominal capacity of $59 \mathrm{~F}$ (50 F measured) and nominal voltage of $15 \mathrm{~V}$ each, operating with the efficiency of $98 \%$. The two mentioned energy storage sources were connected in parallel. The supercapacitor was chosen in order to smooth out peak power demands of the vehicle during acceleration and to supply power for balance of plant (BoP) components during fuel cell start-up. Based on the well-known parameters of energy sources and vehicle motor requirements a hybrid system power controller was constructed. The electronic circuit was integrated with energy sources. The hybrid system power controller input voltage of $10-20 \mathrm{~V} \mathrm{DC}$ and maximum input current of $50 \mathrm{~A}$ was adjusted to fuel cell stack electrical parameters and output parameters of $40 \mathrm{~V} \mathrm{DC}$ and $15 \mathrm{~A}$ were imposed by the scooter electric motor. Figure 1 presents integration layout of the fuel cell hybrid system components. It was assumed that the power source should be able to deliver $300 \mathrm{~W}$ of power, which is enough to supply the electric scooter power trains which are usually equipped with motors up to $250 \mathrm{~W}$ power. In order to ensure a continuous operation of the fuel cell stack it was necessary to install some auxiliary components. Oxygen is delivered to the stack cathode with the aid of the air compressor, and hydrogen is stored in the form of compressed gas. The compressor was selected based on stack air flow rate requirements and it delivers oxidant at the flow rate of $30 \mathrm{dm}^{3} / \mathrm{min}$ and 0.5 bar pressure. Other stack working parameters (temperature, pressure, and humidity) are maintained at optimum values that were determined at the time of the stack testing and described elsewhere [24]. High pressure (125 bar) stainless steel Swagelok gas container with the capacity of $2.5 \mathrm{dm}^{3}$ allows to store $35 \mathrm{~g}$ of hydrogen, which ensures fuel supply for 1 hour of operation. The complete hybrid power source, integrated in the construction of Hy-IEL scooter, is shown in Figure 2.

With the use of a specially designed data storage unit, eleven parameters can be measured in order to provide information about the energy flow and behaviour of the powering 


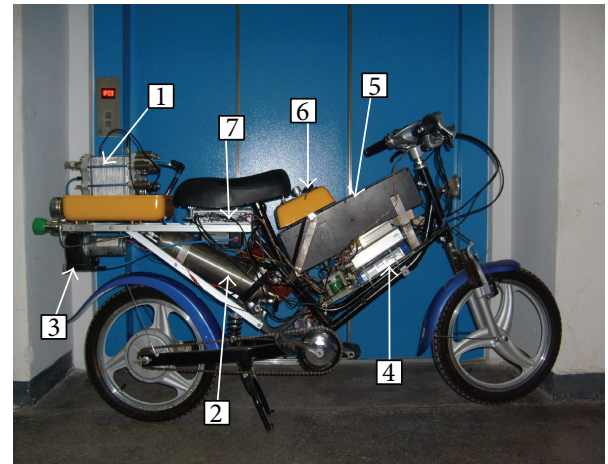

FIGURE 2: Photograph of Hy-IEL electric scooter powered with the hybrid fuel cell-supercapacitor energy source. Components marked in the photograph: 1: fuel cell stack, 2: hydrogen tank, 3: air compressor, 4: supercapacitor, 5: batteries, 6: control panel, 7: data storage unit.

modules, as well as the driving conditions. The voltages and currents of the battery, supercapacitor module and fuel cell are measured, as well as the powering condition of the compressor. Additionally, the hydrogen flow and the velocity of the scooter and its inclination along the driving direction are recorded. The data are stored on a flash memory device (SD card) and can be downloaded to a PC with the use of standard software. More detailed description of the data storage unit topography can be found elsewhere [25].

\section{Experimental Results}

Values of currents and voltages of the hybrid system, as well as the velocity of the vehicle, hydrogen consumption rate, and inclination were measured, and the data stored, during the scooter's field test operation. Data were recorded at a sampling rate of 8 measurements per second. An example of measurement results is presented in Figure 3.

The top characteristic presents voltage values of motor supply, supercapacitor and fuel cell. The voltage that supplies the electric motor of the vehicle is constant although there are many transient disturbances observed which are probably caused by the original electronic control system installed in the scooter. The value of motor supply voltage equals $40 \mathrm{~V}$ and is imposed by the electric motor demands. The voltage of fuel cell and supercapacitor changes depending on the load, within the range from 18 to $10 \mathrm{~V}$. At this condition the power generated by those sources changes from 0 to $250 \mathrm{~W}$. During the start-up and acceleration of the vehicle the energy flows at first from the supercapacitor, which is easily seen in the current characteristic plotted versus time of the trial. The middle characteristic presents current values and its flow direction in the system. In comparison with the supercapacitor, the fuel cell needs more time to generate the required power and both energy sources complement each other. When the supercapacitor is discharged, the fuel cell stack is ready to deliver electric energy for the drivetrain and the surplus of energy is used to charge supercapacitor, which can be observed as negative current values measured for the supercapacitor. The maximum electric motor current

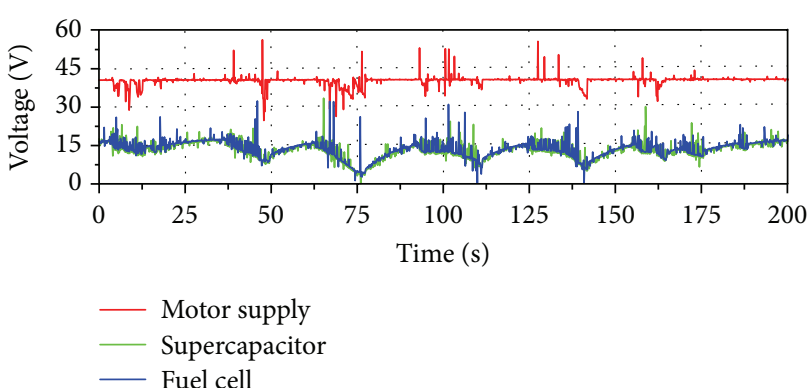

(a)

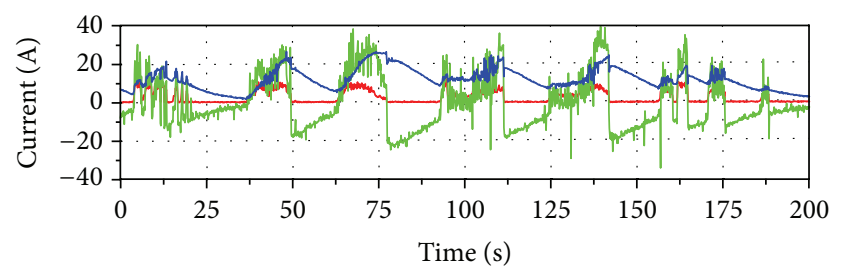

- Motor supply
Supercapacitor
- Fuel cell

(b)

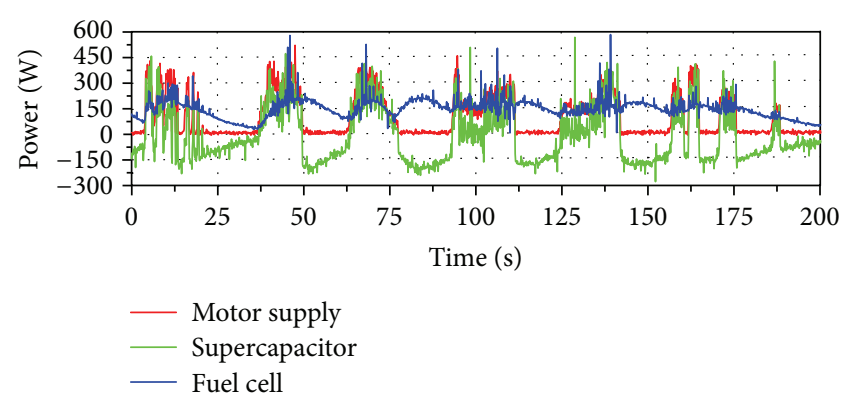

(c)

FIGURE 3: Electrical parameters (voltage, current, and power) of the hybrid system measured during field test of the vehicle.

is about $12 \mathrm{~A}$ but such high values are measured only during the start-up and acceleration of the vehicle. The figure in which power is plotted versus time shows that the power demand from the motor $(350 \mathrm{~W}$ in peak) is higher than the power output from the PEMFC stack ( $200 \mathrm{~W}$ during the test), and the extra power required comes from the supercapacitor. The graph presented in Figure 4 includes results of the measured vehicle velocity, hydrogen consumption rate, and inclination that provide information as to whether the vehicle is moving uphill or downhill. The maximum velocity that the vehicle reached over a short distance of the trial exceeded $10 \mathrm{~km} / \mathrm{h}$. During the start-up and acceleration, when energy is needed, the hydrogen consumption rate increased up to 3 SLPM. Although the test was performed on a horizontal path, without elevations, the installed inclinometer was very sensitive to the vehicle's position and measured changes during braking, which is seen, for example, in the 50th and the 75th seconds of the trial. The previously described parameters provide information about some very important 
TABLE 1: Comparison of fuel cell vehicles.

\begin{tabular}{|c|c|c|c|c|c|c|c|}
\hline $\begin{array}{l}\text { Name of } \\
\text { vehicle }\end{array}$ & Vehicle type & $\begin{array}{l}\text { Motor power } \\
(\mathrm{W})\end{array}$ & $\begin{array}{l}\text { PEMFC stack } \\
\text { power }(\mathrm{W})\end{array}$ & $\begin{array}{l}\text { Second energy } \\
\text { storage }\end{array}$ & $\begin{array}{c}\mathrm{H}_{2} \\
\text { Consumption }\end{array}$ & $\mathrm{H}_{2}$ storage method & $\begin{array}{c}\text { Vehicle speed } \\
(\mathrm{km} / \mathrm{h})\end{array}$ \\
\hline HFCHV [14] & Cart & 4000 & 1200 & $\begin{array}{l}\text { Lead acid } \\
\text { battery }\end{array}$ & $10 \mathrm{~g} / \mathrm{km}$ & $\begin{array}{l}\text { Compressed cylinder } \\
350 \text { bar, } 600 \mathrm{~g} \mathrm{H}_{2}\end{array}$ & 25 \\
\hline MHV [15] & Cart & 4000 & 3200 & - & - & $\begin{array}{l}\text { High pressure cylinder } 10 \mathrm{~L} \\
\text { at } 200 \mathrm{bar}, 1400 \mathrm{Nl} \mathrm{H}_{2}\end{array}$ & - \\
\hline PAB [16] & Bicycle & 230 & 300 & - & - & $\begin{array}{l}\text { Metal hydride tank } 6.8 \mathrm{~g} \text { of } \\
\qquad \mathrm{H}_{2} \text { at }<10 \mathrm{bar}\end{array}$ & 25 \\
\hline PIOS [17] & Tricycle & 300 & 300 & $\begin{array}{l}\text { Lithium } \\
\text { polymer battery }\end{array}$ & 3.7 SLPM & $\begin{array}{l}\text { Composite pressurized } \\
\text { tank } 26 \mathrm{~L} \text { at } 350 \text { bar }\end{array}$ & $40-65$ \\
\hline $\begin{array}{l}\text { HYSYRIDER } \\
{[18]}\end{array}$ & Scooter & 250 & 300 & $\begin{array}{l}\text { Lead acid } \\
\text { battery }\end{array}$ & - & $\begin{array}{l}\text { Low pressure metal hydride } \\
\text { tank, } 200 \mathrm{Nl} \mathrm{H}_{2}\end{array}$ & 20 \\
\hline HFCHS [19] & Scooter & 800 & 500 & $\begin{array}{l}\text { Sealed lead acid } \\
\text { battery }\end{array}$ & 2-3 SLPM & $\begin{array}{l}\text { Metal hydride tank, } 54 \mathrm{~g} \text { of } \\
\qquad \mathrm{H}_{2} \text { at } 15 \mathrm{bar}\end{array}$ & $10-12$ \\
\hline Hy-IEL & Scooter & 250 & 500 & Supercapacitor & 3.0 SLPM & $\begin{array}{l}\text { Stainless steel high pressure } \\
\text { tank } 2.5 \mathrm{~L} \text { at } 125 \mathrm{bar}, 34 \mathrm{~g} \mathrm{H}_{2}\end{array}$ & $10-15$ \\
\hline
\end{tabular}

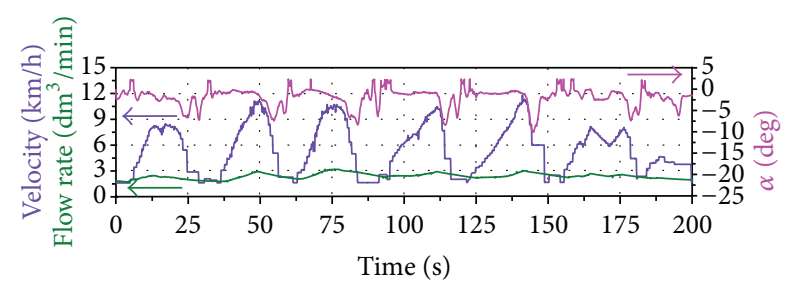

Figure 4: Results of the measured vehicle velocity, hydrogen consumption rate, and inclination versus time.

parameters of the hybrid power supply unit and will be useful for energy balance calculation during future investigations.

In Table 1 there are presented parameters of electric vehicles (carts, bicycles, and scooters) in the construction of which the fuel cell was used to deliver required power to the electric drivetrain. As can be noticed the bigger vehicles like carts are using fuel cell stacks with the power above $1000 \mathrm{~W}$ while the bicycles and scooters have lower power demands and can be powered with smaller units up to $500 \mathrm{~W}$, as in the case presented in the paper on hybrid power source applied in Hy-IEL electric scooter. Different battery types were used for hybridization and most commonly lead acid batteries were applied. The disadvantage of application of the lead acid batteries is their weight and long charging time while supercapacitor used in the Hy-IEL scooter offers much higher energy density. Moreover the charging time of the supercapacitor is very short and it can be charged with high currents which enables application of breaking energy recuperation. Different hydrogen storage methods were used for fuel supply but similar amounts of gas were stored and similar hydrogen consumption for scooter type vehicles was measured. It was reported by authors of HFCHS vehicle that application of metal hydride tank caused problem and sufficient hydrogen flow rate that could not be achieved because of sluggish hydrogen release mechanism [22]. The usage of the pressurised tank seems to be the best option for hydrogen storage in automotive applications. The maximum speed of the scooter class fuel cell vehicles reported in the literature varies from 10 to $65 \mathrm{~km} / \mathrm{h}$ but most of them drive at the speed of about $20 \mathrm{~km} / \mathrm{h}$. This makes the described HyIEL scooter comparable with similar vehicles in this class. The results of the performed field tests of the Hy-IEL scooter were recorded during test on the short distance which can have influence on low vehicle speed that was reported in the paper. Maximum speed of the scooter declared by the producer equals $25 \mathrm{~km} / \mathrm{h}$, but installation of the additional weight decreased the maximum speed to $20 \mathrm{~km} / \mathrm{h}$ that was recorded but not reported in the figures.

\section{Conclusions}

The hybrid fuel cell-supercapacitor power supply system was developed and installed in the electric scooter named HyIEL. The construction of the vehicle was tested during field tests. Experimental results indicate that the developed hybrid power system with a fuel cell-supercapacitor power source is suitable for powering electric vehicles.

The performance of the Hy-IEL electric scooter operating with integrated supercapacitor-fuel cell hybrid power source is similar to previously reported in the literature similar developments. The advantage of the developed power source is application of the supercapacitor which improves the dynamics of energy flow and reduces the weight of the second energy source of the hybrid system. Application of the supercapacitor gives also opportunity for easier braking energy recuperation which will be studied in the future project.

The power system designed and implemented on the vehicle will be modified and used for future research on hybrid systems. The research work will be focused on developing a more sophisticated power control unit, as well as on comparing the experimental results with the calculated energy balance model. 


\section{Acknowledgments}

The authors wish to thank the Polish Ministry of Science and Higher Education for financial support. The presented work was completed under the national Project no., COST/ 261/2006 carried out within the framework of COST Action 542.

\section{References}

[1] D. Ye and Z. Zhan, "A review on the sealing structures of membrane electrode assembly of proton exchange membrane fuel cells," Journal of Power Sources, vol. 231, pp. 285-292, 2013.

[2] A. Morin, F. Xu, G. Gebel, and O. Diat, "Influence of PEMFC gas flow configuration on performance and water distribution studied by SANS: evidence of the effect of gravity," International Journal of Hydrogen Energy, vol. 36, no. 4, pp. 3096-3109, 2011.

[3] F. Alcaide, G. Álvarez, J. A. Blázquez, P. L. Cabot, and O. Miguel, "Development of a novel portable-size PEMFC short stack with electrodeposited Pt hydrogen diffusion anodes," International Journal of Hydrogen Energy, vol. 35, no. 11, pp. 5521-5527, 2010.

[4] H. S. Han, C. Cho, S. Y. Kim, and J. M. Hyun, "Performance evaluation of a polymer electrolyte membrane fuel cell system for powering portable freezer," Applied Energy, vol. 105, pp. 125137, 2013.

[5] H. S. Chu, F. Tsau, Y. Y. Yan, K. L. Hsueh, and F. L. Chen, "The development of a small PEMFC combined heat and power system," Journal of Power Sources, vol. 176, no. 2, pp. 499-514, 2008.

[6] S. F. Tie and C. W. Tan, "A review of energy sources and energy management system in electric vehicles," Renewable and Sustainable Energy Reviews, vol. 20, pp. 82-102, 2013.

[7] F. Wang and Y. Chiang, "Design and control of a PEMFC powered electric wheelchair," International Journal of Hydrogen Energy, vol. 37, no. 15, pp. 11299-11307, 2012.

[8] A. Veziroglu and R. MacArio, "Fuel cell vehicles: state of the art with economic and environmental concerns," International Journal of Hydrogen Energy, vol. 36, no. 1, pp. 25-43, 2011.

[9] T. Larriba, R. Garde, and M. Santarelli, "Fuel cell early markets: techno-economic feasibility study of PEMFC-based drivetrains in materials handling vehicles," International Journal of Hydrogen Energy, vol. 38, no. 5, pp. 2009-2019, 2013.

[10] W. G. Colella, M. Z. Jacobson, and D. M. Golden, "Switching to a U.S. hydrogen fuel cell vehicle fleet: the resultant change in emissions, energy use, and greenhouse gases," Journal of Power Sources, vol. 150, no. 1-2, pp. 150-181, 2005.

[11] C. Wang, S. Zhou, X. Hong, T. Qiu, and S. Wang, "A comprehensive comparison of fuel options for fuel cell vehicles in China," Fuel Processing Technology, vol. 86, no. 7, pp. 831-845, 2005.

[12] L. Barelli, G. Bidini, and A. Ottaviano, "Optimization of a PEMFC/battery pack power system for a bus application," Applied Energy, vol. 97, pp. 777-784, 2012.

[13] O. Erdinc and M. Uzunoglu, "Recent trends in PEM fuel cellpowered hybrid systems: Investigation of application areas, design architectures and energy management approaches," Renewable and Sustainable Energy Reviews, vol. 14, no. 9, pp. 2874-2884, 2010.

[14] L. Cardinali, S. Santomassimo, and M. Stefanoni, "Design and realization of a $300 \mathrm{~W}$ fuel cell generator on an electric bicycle," Journal of Power Sources, vol. 106, no. 1-2, pp. 384-387, 2002.

[15] K. Kendall, B. G. Pollet, A. Dhir, I. Staffell, B. Millington, and J. Jostins, "Hydrogen fuel cell hybrid vehicles (HFCHV) for
Birmingham campus," Journal of Power Sources, vol. 196, no. 1, pp. 325-330, 2011.

[16] J. J. Hwang, D. Y. Wang, and N. C. Shih, "Development of a lightweight fuel cell vehicle," Journal of Power Sources, vol. 141, no. 1, pp. 108-115, 2005.

[17] J. Weigl and H. Saidi, "Pios hydrogen fuel cell tricycle," International Journal of Hydrogen Energy, vol. 30, no. 9, pp. 1035-1036, 2005.

[18] E. Novo, L. Baldini, L. Borello, P. Cherchi, G. Gianolio, and N. Valtuegna, "Development of fuel cell hybrid scooter equipped with an integrated metal hydride tank," in HYSYDAYS 1st World Congress of Young Scientists on Hydrogen Energy Systems, pp. 405-407, 2006.

[19] N. Shih, C. Lin, C. Chang, and D. Wang, "Experimental tests of an air-cooling hydrogen fuel cell hybrid electric scooter," International Journal of Hydrogen Energy, 2013.

[20] P. Thounthong, S. Raël, and B. Davat, "Control strategy of fuel cell/supercapacitors hybrid power sources for electric vehicle," Journal of Power Sources, vol. 158, no. 1, pp. 806-814, 2006.

[21] P. Rodatz, G. Paganelli, A. Sciarretta, and L. Guzzella, "Optimal power management of an experimental fuel cell/supercapacitor-powered hybrid vehicle," Control Engineering Practice, vol. 13, no. 1, pp. 41-53, 2005.

[22] J. L. Shang and B. G. Pollet, "Hydrogen fuel cell hybrid scooter (HFCHS) with plug-in features on Birmingham campus," International Journal of Hydrogen Energy, vol. 35, no. 23, pp. 1270912715, 2010.

[23] A. Jossen, J. Garche, H. Doering, M. Goetz, W. Knaupp, and L. Joerissen, "Hybrid systems with lead-acid battery and protonexchange membrane fuel cell," Journal of Power Sources, vol. 144, no. 2, pp. 395-401, 2005.

[24] P. Bujlo, Polimeric, superionic membranes for PEM fuel cells [Ph.D. thesis], Wroclaw University of Technology, Wroclaw, Poland, 2006, http://www.dbc.wroc.pl/Content/1539/Bujlo+ Piotr+Rozprawa+Doktorska.pdf.

[25] P. Bujło, A. Sikora, G. Paściak, and J. Chmielowiec, "Energy flow monitoring unit for Hy-IEL hybrid (PEM fuel cellsupercapacitor) electric scooter," Przeglad Elektrotechniczny, vol. 86, no. 3, pp. 271-273, 2010. 


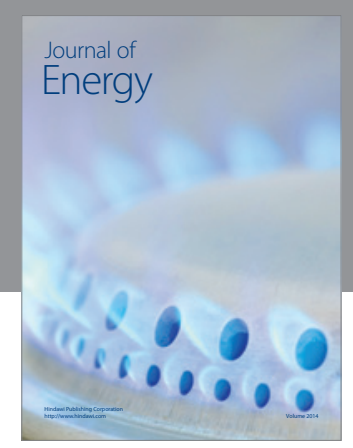

Journal of

Industrial Engineering
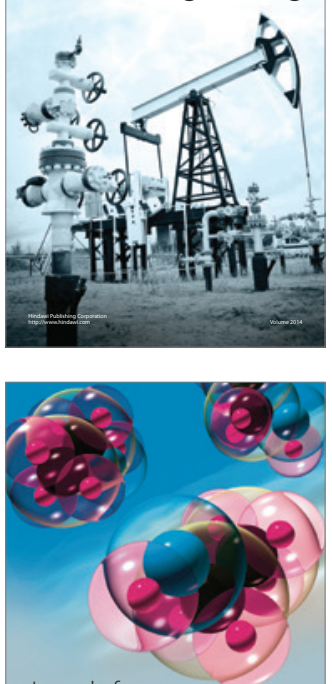

Fuels
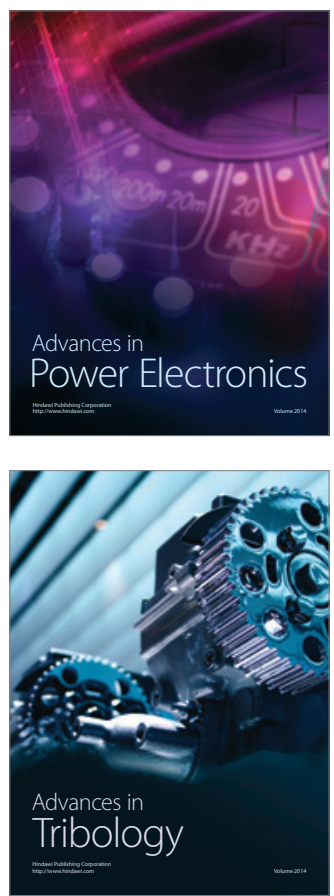

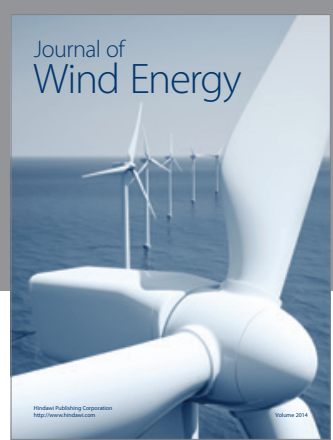

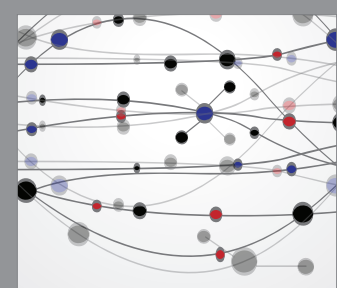

The Scientific World Journal

Submit your manuscripts at http://www.hindawi.com

Journal of

Structures
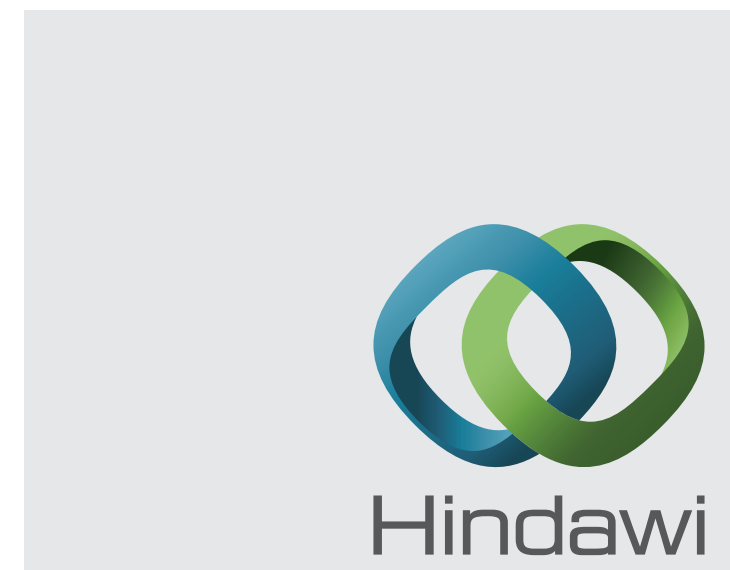

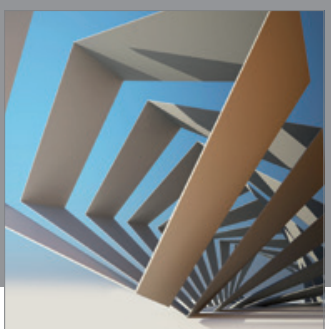

Rotating

Machinery
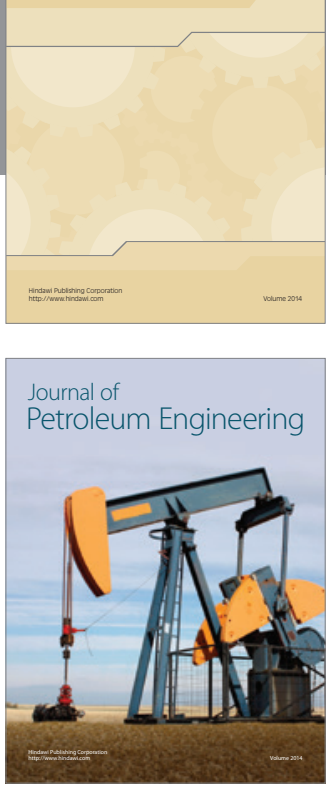

Journal of

Solar Energy
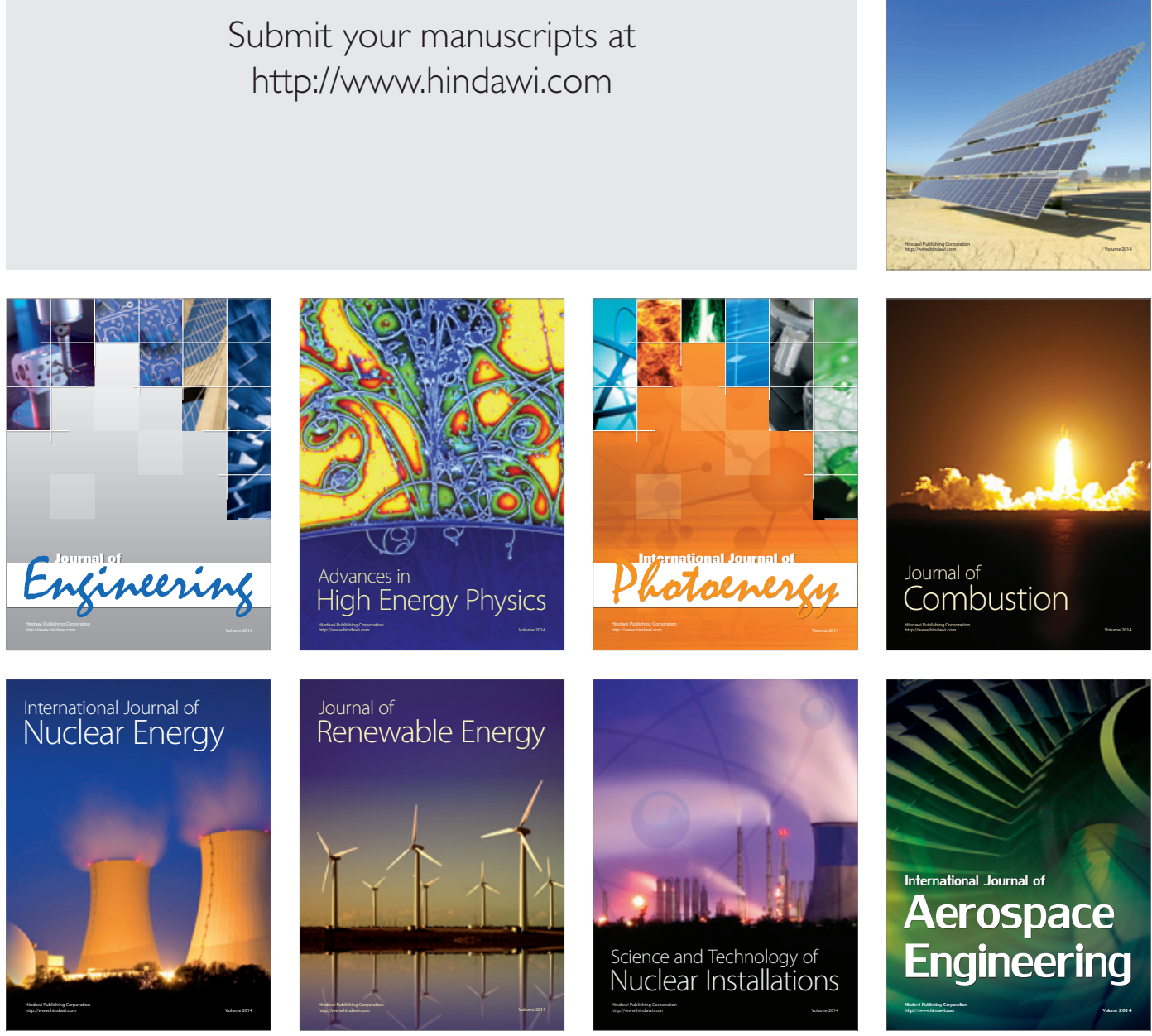